\title{
EL CICLO DE IMAGGENES DEL CANCIONERO DE ZARAGOZA EN LOS TESTIMONIOS INCUNABLES (92VC Y 95VC)*
}

\author{
María Jesús Lacarra \\ Universidad de Zaragoza-IPH \\ jlacarra@unizar.es
}

Los hermanos Hurus, Pablo y Juan, se caracterizaron por imprimir en Zaragoza en el periodo incunable libros muy bellos, con frecuencia acompañados de ilustraciones y con gran dependencia de los talleres germanos, sin excluir la producción propia en algunos casos. Esta conocida afirmación se ejemplificaba con obras como la Cárcel de amor (1493), Las mujeres ilustres en romance (1494), o, sobre todo, el Viaje de la Tierra Santa (1498), entre otras, aunque en esta nómina deberá incluirse el llamado Cancionero de Zaragoza (92VC y 95VC). Sus 60 (59) estampas, del ancho de columna, no han merecido la atención de los estudiosos, aunque suponen la temprana aparición en las prensas hispanas de un amplio corpus de imágenes religiosas, cuya circulación, a veces a través de copias, se prolongará durante el siglo XVI. La razón de este olvido obedece a los complejos enredos de su transmisión bibliográfica, que ha desvelado brillantemente Mercedes Fernández Valladares ${ }^{1}$.

\footnotetext{
*Este trabajo se ha realizado en el marco del Proyecto de Investigación FFI2016-75396-P, concedido por el Ministerio de Economía y Competitividad. Se inscribe en el grupo investigador Clarisel, que cuenta con la participación económica tanto del Departamento de Ciencia, Tecnología y Universidad del Gobierno de Aragón como del Fondo Social Europeo. Agradezco a M. ${ }^{a}$ Carmen Lacarra Ducay la ayuda prestada en la descripción de algunas imágenes.

${ }^{1}$ Este artículo parte de dos importantes trabajos aparecidos en fechas recientes: Mercedes Fernández Valladares, «Dos ejemplares recuperados del Cancionero de Zaragoza (92VC) con sorpresa inserta: unas desconocidas Coplas del Quicumque vult y dos nuevos fragmentos de La Pasión trovada y de la Vita Christi》, en Revista de Cancioneros Impresos y Manuscritos, 8 (2019), pp. 50-106. [En línea]. Enlace: $<$ http://www.cancioneros.org/rcim/> [Consulta: 9/1/2020] y Julián Martín Abad, Cum Figuris. Texto e imagen en los incunables españoles. Catálogo bibliográfico y descriptivo, pról. Elisa Ruiz, Madrid, Arco Libros, 2018, con reproducción también de varias estampas de 92VC y 95VC. Remito al artículo de M.
} 


\section{La recuperación de los testimonios de las dos ediciones: 92 VC y 95VC}

Tras los recientes hallazgos, hoy contamos con tres ejemplares de este bello Cancionero, dos de la primera edición (92VC) y uno de la segunda (95VC), gracias a los cuales podemos reconstruir todo su ciclo de imágenes, pues los fallos de unos se suplen con los otros. Desde el último tercio del pasado siglo se conocía la existencia de un testimonio de la segunda edición, finalizada el 10 de octubre de 1495, conservado en la Biblioteca Universitaria Alessandrina de Roma, que fue localizado por Keith Whinnom mientras trabajaba sobre Diego de San Pedro ${ }^{2}$. Perteneció a Francesco Maria II della Rovere (1549-1631), último duque de Urbino, cuya Libraria impressa, como se conocía a la colección, abunda en textos españoles. El Duque debió de adquirir este ejemplar ya falto de portada, pues está recompuesto el fol. 1: se ha pegado la hoja de la Tabla y añadido el título que encontramos en el testimonio de la BNE de $92 \mathrm{VC}^{3}$.

Distintas referencias apuntaban a la existencia de una primera edición de 1492, de la que se tenían noticias dispersas de dos ejemplares diferentes. Uno de ellos formó parte de la colección del librero y bibliófilo Pedro Salvá y Mallén (1811-1870), como se describe en el Catálogo de su biblioteca, publicado póstumamente en 1872 , un año antes de su puesta a la venta en Londres en 1873. La mayor parte de la misma fue adquirida por el industrial y también bibliófilo malagueño Ricardo Heredia y Livermore, Conde

Fernández Valladares para los pormenores bibliográficos de ambos incunables, que me limito a exponer de forma sucinta, y al repertorio de J. Martín Abad para una descripción detallada de las imágenes en los n. ${ }^{\circ} 192$ (92VC) y n. ${ }^{\circ} 206$ (95VC), con indicación de las reutilizaciones, copias o imitación de las mismas en otros incunables; por lo tanto se insistirá aquí solo en las no incluidas en ese catálogo.

${ }^{2}$ Diego de San Pedro, Obras completas, I. Tractado de amores de Arnalte y Lucenda. Sermón, ed. de Keith Whinnom, Madrid, Clásicos Castalia, 1973, p. 43, nota 80. Se recogía en distintos catálogos bibliográficos desde Nicolás Antonio, quien fue el primero en dar noticia de esta edición en su Bibliotheca Hispana Nova, 1788, 581'a; Ramón Diosdado Caballero, De prima typographie hispanice aetate specimen Romae apud Antonium Fulgonium, 1793, n. ${ }^{\circ}$ 151; Francisco Méndez, Typographía española o historia de la introducción, propagación y progresos del arte de la imprenta en España, Madrid, 1796, n. ${ }^{\circ}$ 18; Konrad Haebler, Bibliografia Ibérica del siglo XV. Enumeración de todos los libros impresos en España y Portugal hasta el año de 1500, con notas críticas, La Haya, etc., Martinus Nijhoff, etc., 1903-1917, 2 v. (ed. facsímil: Madrid, Julio Ollero, 1992), n. ${ }^{\circ} 424$; Juan Manuel Sánchez, Bibliografia zaragozana del siglo XV, Madrid, Imprenta Alemana, 1874, n. $^{\circ}$ 50. Miguel Ángel Pallarés Jiménez, La imprenta de los incunables de Zaragoza y el comercio internacional del libro a finales del siglo xv, Zaragoza, Institución Fernando el Católico, 2003, n. ${ }^{\circ}$ 89, atribuido erróneamente a Íñigo López de Mendoza.

${ }^{3}$ Signatura Inc. 382. María Luisa Cerrón Puga, Los libros del Duque: Un recorrido por la espiritualidad y la ciencia en tiempos de la Contrarreforma: La colección de libros españoles de Francesco Maria II della Rovere (1549-1631) en el Fondo Urbinate de la Biblioteca Universaria Alessandrina de Roma, Roma, Rotastampa, 2010, n. ${ }^{\circ} 3$. 
de Benahavís (1831-1896), cuyos fondos se vendieron en París en subasta pública ${ }^{4}$. Finalmente el volumen fue comprado por Jean Masson (18561933), empresario y coleccionista, gran parte de cuyos libros fueron a parar a l'École Nationale Supérieure des Beaux-Arts de París, donde actualmente se encuentran. En la parte inferior del folio 113 figura, a la izquierda, el sello del coleccionista, con sus iniciales inscritas (JM) dentro de un círculo, y, a la derecha, el sello de la biblioteca. En 1902 Jean Masson lo expuso en una muestra sobre el grabado en madera, como se desprende de la lectura del Catálogo, donde figura, en el apartado dedicado a Hurus, como «Cancionero de varias coplas devotas, s.d. (Xv siècle) $)^{5}$. Se trata de un ejemplar mútilo, sin portada y colofón, por lo que fue considerado otro testimonio más de la edición publicada en $1495^{6}$.

En fechas muy recientes a este ejemplar se ha sumado otro, mútilo de 18 hojas (de la 36 a la 53), que figuraba en manos particulares hasta su adquisición en 2018 por la Biblioteca Nacional, tras un largo y complicado proceso. Le faltan 22 estampas correspondientes al texto original de la Pasión trobada de Diego de San Pedro, sustituido por otro sin ilustrar, posible indicio de una edición del mismo taller (¿Cancionero completo?), anterior y más pobre, al que hipotéticamente se le podrían asignar las siglas $91 * \mathrm{VC}$. Sin embargo, cuenta con el colofón, que falta en el parisino: «Çarragoça: por industria et expensas de Paulo hurus de Cōstancia aleman, 27 nov. 1492». Perteneció a la Compañía de Jesús de la Concepción de Sevilla, y figuraba en la biblioteca de Jovellanos, donde estaba encuadernado junto a las Coplas del menosprecio e

\footnotetext{
${ }^{4}$ Pedro Salvá y Mallén, Catálogo de la Biblioteca de Salvá... enriquecido con la descripción de otras muchas obras, de sus ediciones, etc., Valencia, Imp. de Ferrer de Orga, 1872. 2 v. (ed. facsímil: Madrid, Julio Ollero, 1992), n. ${ }^{\circ}$ 186, y Ricardo Heredia, Conde de Benahavís, Catalogue de la bibliothèque de M. Ricardo Heredia, Comte de Benahavis, Paris, Ém. Paul, L. Huard et Guillemin, 1891-1894, n. ${ }^{\circ}$ 1643; Pallarés Jiménez, ob. cit., n. ${ }^{\circ}$ 64, lo atribuyó también erróneamente a Íñigo López de Mendoza.

${ }^{5}$ Exposition de la gravure sur bois a l'École Nationale des Beaux-Arts, mai 1902, París, Librarie de l'art ancien et moderne, 1902, n. ${ }^{\circ}$ 281. Sobre este coleccionista, véase [En línea]. Enlace: $<$ http://www. marquesdecollections.fr/detail.cfm/marque/7817> [Consulta: 9/1/2020].

${ }^{6}$ Signatura Masson 2055. Ejemplar, también mútilo, al que le faltan los folios I-III, VII-VIII y XXXVII. El catálogo online de la Biblioteca parisina está rectificado, pero no las bases de datos, ISTC im00489200 y GW M18729, que incorporan erróneamente el testimonio de París (1492) junto al de Roma (1495). Debemos a Fernández Valladares, art. cit., la corrección de esta identificación. ISTC: The Incunabula Short Title Catalogue [International database of 15th-century European printing, created by the British Library with contributions from institutions worldwide]. Enlace: <http://www.bl.uk/catalogues/istc/ index.html> [Consulta: 10/1/2020] y GW: Gesamtkatalog der Wiegendrucke, Hrsg. von der Kommision für Gesamtkatalog der Wiegendrucke. 2. Aufl. Stuttgart, etc., Anton Hiersemann, 1968- (en publicación). Accesible en red: Staatsbibliothek zu Berlin; Gesamtkatalog der Wiegendrucke / Inkunabelsammlung; Union Catalogue of Incunabula / Incunabula Collection. Enlace: <https://www.gesamtkatalogderwiegendrucke.de/GWEN.xhtml> [Consulta: 10/1/2020].
} 
contempto de las cosas fermosas del mundo del infante don Pedro de Portugal, y fue adquirido por Pedro Vindel hace más de 80 años ${ }^{7}$.

La obra es una antología poética, de contenido exclusivamente devocional, encabezada por las Coplas de Vita Christi de Íñigo de Mendoza, pero en la que se incluye asimismo la obra de otros diez poetas, como Diego de San Pedro, Juan de Mena o Jorge Manrique, hasta alcanzar un total de 16 piezas. Esta circunstancia ha hecho también que se le haya designado de distintas formas, Cancionero de Mendoza, Cancionero de fray Íñigo de Mendoza, Cancionero de Hurus, Coplas de Vita Christi, Fray Ínigo de Mendoza y otros, Vita Christi fecho por coplas de Ínigo de Mendoza, Cancionero de coplas y obras devotas, Cancionero de Zaragoza, Devotionum opus, Coplas devotas, etc., lo que ha contribuido, sin duda, a las confusiones en su localización y catalogación. En el taller de los hermanos Hurus este Cancionero no supone una excepción. Como ha estudiado Romero Tobar ${ }^{8}$, junto a este se publican otros libros poéticos, colectivos o individuales, como el Tractado del cuerpo e del ánima de Antón López de Meta (1485-1491), el Cancionero de Ramón de Llavia (1488-1490), el Catón de Martín García y la versión de Gonzalo García de Santa María, las Coplas del menosprecio del mundo del Infante de Portugal (1488-1490), los Proverbios de Íñigo López de Mendoza (1488-1490), el Laberinto (1489) y la Coronación (1490-1491) de Juan de Mena (1489), o el Triunfo de María de Martín Martínez de Ampiés (1495). De ellos, solo el Triunfo de María está ilustrado con grabados parcialmente coincidentes con los del Cancionero, mientras que el Cancionero de Ramón de Llavia, otra antología de carácter religioso-moral, carece de ellos. Como señala Antonio Rodríguez Moñino al respecto de esta antología

quien la ordenó, si no la hizo el propio fray Íñigo, ciertamente fue persona de conocimiento, criterio acertado y buen gusto, que aspiró a poner en manos devotas un poético Libro de Horas castellano, iniciado con la Vida de Cristo y seguido de cinco obras relativas a la Pasión, cuatro piezas marianas, dos de tipo doctrinal, la famosa Justa de la Razón contra la Sensualidad, para concluir con las Coplas de Jorge Manrique y el Decir de la Muerte de Fernán Pérez de Guzmán.

\footnotetext{
${ }^{7}$ Cuenta con la signatura INC/2900 y gracias a su digitalización actual pueden verse todas las imágenes. Enlace: <http://bdh-rd.bne.es/viewer.vm?id=0000251821\&page=1> [Consulta: 9/1/2020]; véase Francisco Aguilar Piñal, La biblioteca de Jovellanos (1778), Madrid, CSIC-Instituto «Miguel de Cervantes», 1984, n. ${ }^{\circ} 467$, y Fernández Valladares, art. cit.

${ }^{8}$ Leonardo Romero Tobar, «Los libros poéticos impresos en los talleres de Juan y Pablo Hurus», en Aragón en la Edad Media, 8 (1989), pp. 561-574.
} 
Destacaba también el bibliógrafo y filólogo, «la perfecta unidad temática religioso-moral de sus poemas y el ser todos de metro corto, tan fácil para la divulgación o incluso para retener en la memoria entre gentes sencillas, estando destinado a un público popular» ${ }^{9}$.

En resumen, de la primera edición ilustrada (92VC), que hasta hace poco se consideraba perdida, contamos en estos momentos con dos testimonios felizmente recuperados, parcialmente incompletos, en París y en la Biblioteca Nacional de España, a los que se suma el de su reedición en 1495 (95VC) en Roma. Dejando a un lado el estudio de su contenido, mi objetivo en este momento es aproximarme a las estampas para lo cual tendré en cuenta los tres ejemplares. Esta disociación, solo a efectos prácticos, no debe hacernos olvidar que texto e imagen forman una unidad.

\section{Paralelismos y divergencias entre 92VC y 95VC}

Gracias a la existencia de dos testimonios del impreso de 1492, y a que la edición de 1495 sigue la anterior, podemos reconstruir el conjunto de imágenes que adornaba este Cancionero. La edición de 1492 estaría ilustrada con 60 estampas (más la marca tipográfica), 15 de ellas repetidas, pero no ha llegado ningún ejemplar completo. Al conservado en París le faltan dos grabados, la Anunciación (n. $\left.{ }^{\circ} 1\right)$ y la Oración de Jesús en Getsemaní (n. $\left.{ }^{\circ} 10\right)$, que pueden recuperarse, el primero con el testimonio conservado en la BNE $\mathrm{y}$ el segundo, gracias a la edición de $1495^{10}$. Por el contrario, al ejemplar de la BNE, que tiene interpoladas 40 hojas con una Pasión trovada sin estampas, le faltan 22 (del n. ${ }^{\circ} 10 \mathrm{al} \mathrm{n}^{\circ}{ }^{\circ} 27 \mathrm{c}$, ambos incluidos). Pese a que el impreso de 1495 se considera copia 'a plana y renglón' de 1492, se distingue por algunas diferencias que afectan al número de estampas y, en algún caso, a los tacos empleados. En esta ocasión hay 59 estampas, sin contar la marca, de las cuales 16 están repetidas; no se trata de un fallo del ejemplar único sino de una deliberada exclusión de la última imagen ( . $^{\circ}$ 54, «La Muerte»). A esto hay que sumar en dos ocasiones la elección de otras maderas, bien porque no estaban disponibles en el taller o por su deterioro, para representar algunos de los motivos más reiterados en la iconografía religiosa, como la Natividad o la Ascensión.

${ }^{9}$ Antonio Rodríguez Moñino, Estudios y ensayos de literatura hispánica de los Siglos de Oro, ed. de Víctor Infantes, Cáceres, Ediciones Genueve, 2012, pp. 108-109.

${ }^{10}$ En este trabajo me referiré siempre a las imágenes por el número correspondiente al de la tabla adjunta en apéndice. 
La Natividad se ilustra en $92 \mathrm{VC}$ dos veces, pero con tacos diferentes. En ambos se muestra un Niño Jesús radiante con su madre al lado; al fondo, la mula y el buey. En el primero (n. $\left.{ }^{\circ} 2\right)$, tres ángeles sostienen una filacteria (Gloria in Excel[sis] deo) con el texto de su cántico, y San José contempla la escena desde el exterior del portal de Belén, iluminándola con un farolito. Pese a ser invierno, el suelo está lleno de flores, al igual que sucede con el árbol florido en la «Huida a Egipto» (n. $\left.{ }^{\circ} 6\right)$. La estampa $n .^{\circ} 2$ se encontraba ya en el taller, puesto que fue utilizada en las Horae ad usum Romanorum [Zaragoza: taller de los hermanos Hurus, c. 1490] y en la primera impresión de Aurea Expositio, el 26 de enero del mismo año 1492. En la segunda (n. ${ }^{\circ}$ 48), de líneas más simples y sin ángeles, San José está junto a la Virgen, adorando al Niño, con un cayado sobre su hombro izquierdo, símbolo de su ancianidad. Esta imagen procede de la Legenda aurea, Lyon: Mathias Huss, $1486^{11}$, y se utilizó en las Orationes ad plenum collectae, [Burgos]: Fadrique de Basilea, [c.1498], h.1v y en el Flos sanctorum romançat, Barcelona: Joan Rosenbach, 1494, h. 23r.

En la reedición de 1495 se usa un modelo distinto que pertenece a otra serie iconográfica $\left(\mathrm{n}^{\circ}{ }^{\circ}{ }^{*}\right)$. El Niño Jesús aparece recostado sobre un paño, junto a la Virgen hay otra mujer joven y san José llega con una vela encendida; esa luz, al igual que la del fanal, nos indica que el Nacimiento tuvo lugar de noche, pero desde el punto de vista simbólico está eclipsada por los rayos del Niño ${ }^{12}$. De acuerdo con los Evangelios apócrifos (Pseudo Mateo, XIII, 4-5) y el Evangelio árabe de la infancia (III, 1-5), la segunda mujer es la comadrona Salomé asistente al parto, que dudó en un primer momento de la virginidad de María y luego arrepentida acompañó a la Sagrada Familia hasta tierras de Egipto $^{13}$. Esta misma imagen se repite en el f. $75 \mathrm{r}\left(\mathrm{n} .{ }^{\circ} 48^{*}\right)$, lo que explica que el número de grabados reutilizados supere al del impreso de 1492. También

${ }^{11}$ BNF [Illustrations de Legenda Sanctorum] / Lyon: Mathias Huss, [1486] Enlace: <https://gallica. bnf.fr/ark:/12148/btv1b2200010q/f2.item> [Consulta: 10/1/2020].

${ }^{12}$ Según Sandra de Arriba Cantero, «San José», en Revista Digital de Iconografia Medieval, 5:10 (2013), pp. 57-76 (p. 59): «En el caso de la vela, regularmente sustituida por una lámpara o fanal (tabla de la Natividad, iglesia de Santa María del Castillo de Frómista, siglo Xv), fue santa Brígida de Suecia quien afirmó en sus Revelaciones haber visto al santo llevando este objeto en la Natividad durante un trance místico ante la gruta del pesebre [...]. Iconográficamente, esta idea da como resultado un Niño envuelto en rayos o mandorla dorada que comparte con su madre mientras, a su lado, el anciano José ha de conformarse con la tenue llama del candil (Natividad del Maestro de Ávila, Museo Lázaro Galdiano, siglo xv). Se trataría, en resumen, de la clásica contraposición entre lo espiritual y lo material, lo divino y lo humano».

${ }^{13}$ La historia del arrepentimiento de la comadrona se recoge en los Evangelios Apócrifos de la Natividad. En una tabla gótica del Museo de Zaragoza dedicada a la Huida a Egipto (c. 1390-1400), procedente de la iglesia de Santa María de Alpuente (Segorbe), Salomé camina detrás de la Sagrada Familia llevando la cuna del Niño y otros enseres; véase M. ${ }^{a}$ Carmen Lacarra Ducay, Arte Gótico en el Museo de Zaragoza, Zaragoza, Gobierno de Aragón, 2003, pp. 32-33, figuras 25 y 25-1. 
se encuentra en el Triunfo de María (1495, h. 57v), Aurea expositio (c. 1495, h.23v, y 1499, h. 22r), Viaje de la Tierra Santa (1498, h.72r) o en las Horae (1499, Coci; Hutz y Appenteger, h. 87v y 1500, h. 107v y h. 113v).

Para la representación de la Ascensión de Jesús de nuevo se recurre a dos modelos en $92 \mathrm{VC}$. En el n. ${ }^{\circ} 39$ Jesús desaparece entre nubes radiantes y solo se ven parcialmente su túnica y sus pies. Los apóstoles están arrodillados en torno a un montículo, en una imagen empleada también en el Aurea expositio, 26 enero 1492 y c. 1495 . En la estampa n. ${ }^{\circ}$ 50b solo se ven los pies de Jesús y sus huellas en un montículo; alrededor se encuentran los apóstoles y delante, dos arbolitos. La imagen, como veremos más adelante, procede de la Legenda aurea, Lyon: Mathias Huss, 1486. En 95VC se recurre para la representación de esta escena en el folio 69r a la misma estampa que en 92VC (n. $\left.{ }^{\circ} 39\right)$, pero en el f. $76 \mathrm{r}$ se emplea otro modelo diferente (n. $\left.{ }^{\circ} 50 \mathrm{~b}^{*}\right)$, que fue utilizado en el taller en el Triunfo de María, 1495, el Viaje de la Tierra Santa, 1498, las Horae, 1499 y en Aurea expositio, 1499.

Por último, desaparece la estampa que acompañaba el breve decir anónimo de la Muerte (f. $112 \mathrm{v}, \mathrm{n}^{0} 54$ en $92 \mathrm{VC}$ ) ${ }^{14}$, en la que la Muerte triunfante, en forma de esqueleto con un ataúd en el brazo derecho y una flecha, símbolo de la peste, en su mano izquierda, camina por un campo lleno de calaveras con tiaras, mitras y coronas, rodeada por una filacteria con la leyenda: Nemini parco qui vivit in orbe. El grabado, que retoma un motivo iconográfico muy común, se usó en el mismo taller en el Cordial, 21.VII.1491, y se disocia de los demás por su mayor formato (135x $85 \mathrm{~mm})$, por lo que ocupa el ancho de página, frente al resto, que oscila entre 90 x $65 \mathrm{~mm}$ y 52 x $41 \mathrm{~mm}$, y se reducen al ancho de columna.

En la mayoría de los casos se corresponden directamente con el contenido, con los epígrafes y, a veces, con los titulillos. Su distribución, sin embargo, no es regular, por lo que no sirven para estructurar el Cancionero, aunque sí para destacar los momentos más significativos y dramáticos y para reforzar su recuerdo. Son imágenes descriptivas que apoyan el texto, y en ocasiones lo anuncian y ayudan a identificarlo. Pese a estar ceñidas al contenido, su propia temática facilita su reutilización tanto en otros momentos del mismo Cancionero como en otras obras. La mayoría se insertan en aquellas piezas cuyo contenido se centra en la vida y pasión de Cristo, lo que explica la necesaria repetición de imágenes. En proporción son las Coplas de la pasión de nuestro redemptor trobadas de Diego de San Pedro las que incluyen un

${ }^{14}$ Dutton [ID2902] 95VC-16 (112v). 
mayor número de estampas $(22)^{15}$, seguidas de la Obra de la resurrección de nuestro redemptor de Pero Ximénes (9), y la Vita Christi de Íñigo de Mendoza (7); en menor grado se ilustran las Coplas en que pone la Cena que nuestro Salvador hizo (2) también de Íñigo de Mendoza. Frente a la vida y pasión de Cristo, otro ciclo tiene como protagonista a la Virgen, con los poemas de Íñigo de Mendoza, Obra de los siete gozos de Nuestra Señora (7), Diego de San Pedro, Coplas de las siete angustias de Nuestra Señora (7), Ínigo de Mendoza Coplas a la Verónica (3), Juan Guillardón, Coplas sobre el Ave Maris Stella (1) y las Coplas de la historia de la sacratissima Virgen María del Pilar de Çarragoca (sic) de Gonzalo Martínez de Medina (1); las Coplas en loor de Nuestra Señora de Ervías no cuentan con imágenes. El tercer núcleo temático, centrado en la meditación de índole filosófica, moral y religiosa, se abre con las Coplas contra los siete pecados mortales de Juan de Mena, la Obra de los diez mandamientos et de los siete peccados mortales con sus virtudes contrarias de Juan de Ciudad Rodrigo, las Coplas de la justa de la razón contra la sensualidad de Íñigo de Mendoza y las Coplas a la muerte de su padre de Jorge Manrique, y se cierra con un breve Dezir de la muerte, anónimo seguido del Dezir gracioso et sotil de la muerte, de Fernán Pérez de Guzmán. En este tercer bloque solo el Dezir anónimo está presidido por una estampa, que parece anunciar el final, abarcando también el poema de Pérez de Guzmán, careciendo el resto de ilustraciones. Esta situación no es sorprendente. La literatura devocional, como los libros de horas o la Leyenda dorada, se decoraba profusamente en la imprenta europea, siguiendo el modelo de los manuscritos, aunque ahora fuera accesible para un amplio público. Esto implicaba la circulación de un gran número de xilografías que se reusaban, retocaban o copiaban por doquier; por el contrario, la última sección, de contenido más local, carecía de la misma tradición iconográfica.

En resumen, el Cancionero se mueve en una progresión que va de la vida y muerte de Cristo a la de cualquier ser mortal, pues «toda tu gentileza y fermosura loada conviene de ser tornada gusanos y grand vileza» (f. 113v). Pese a la similitud entre ambas ediciones, el producto final impreso en 1492 tendría una mayor coherencia iconográfica que $95 \mathrm{VC}$, al abrirse con una estampa de la Anunciación (n. $\left.{ }^{\circ} 1\right)$ y cerrarse con una imagen de la Muerte (n. ${ }^{\circ}$ 54), que destacaba por su mayor formato y servía de adecuado broche del conjunto. En el apéndice final (tabla 1) queda esquematizada la distribución de las estampas en los tres ejemplares conservados.

${ }^{15}$ La abundancia de imágenes en la Pasión trobada pudo originar, a juicio de Fernández Valladares, art. cit., que este bloque se desgajara del ejemplar de 1492 para su venta independiente y fuera sustituido por 40 hojas interpoladas de otra edición previa sin estampas. 


\section{Las estampas y sus modelos}

Frente a una previa edición más económica sin estampas, Pablo Hurus apostó en 1492 por un producto más bello y costoso, ilustrado con 60 estampas. Esta edición de lujo implica un cambio radical en el aspecto del libro, que incidirá y condicionará su lectura. La decisión fue acertada y por ello se repitió, con mínimas modificaciones, en 1495, pero estos grabados no mantienen una unidad estética, ya que corresponden a distintas series iconográficas, que he podido identificar en algunos casos.

El grupo más numeroso, y de mayor calidad, mantiene una relación directa con grabados de Martin Schongauer. Son claras las correspondencias con diez de ellos, los números 10, 11, 12, 18, 20a, 21, 24, 27b, 32 y 33; a estos podemos sumar otros dos, inspirados más remotamente en otros del mismo artista, n. $^{\circ} 22$, y n. ${ }^{\circ}$ 52; este último, como la Crucifixión (n. $\left.{ }^{\circ} 24\right)$, retoma obras de juventud, 1470-1475. La amplia circulación de los grabados del pintor y grabador alsaciano Martin Schongauer, c. 1450-1491, se inició ya en vida del artista. Sus temas preferidos corresponden a la iconografía religiosa y dentro de ella, dos series sobre cobre, el ciclo de la Pasión y la Vida de la Virgen, fueron las más populares. La primera incluye doce grabados, realizados entre 1473 y 1489, que se inician con la Oración de Jesús en Getsemaní y finalizan con la Resurrección de Cristo. La gran difusión de su obra alcanzó también a la Península Ibérica hasta el punto de que se ha especulado con su presencia en España en los últimos años de su vida ${ }^{16}$. Pese a que no se ha podido documentar este desplazamiento, su huella sobre la pintura gótica aragonesa es especialmente relevante, superior a la del resto de la Península, lo que ha llevado a pensar en un doble influjo, en el que algunos grabados insertos en libros devotos impresos por Pablo Hurus hubieran servido también de fuente de inspiración a los artistas. Cabe añadir que entre el círculo de amistades del impresor figuraban también artistas, escultores y pintores, residentes en la ciudad ${ }^{17}$. Hasta ahora se habían estudiado los paralelismos entre algunas estampas de Schongauer y las incluidas en obras como el Tesoro de la pasión

${ }^{16}$ Fedja Anzelewsky, «Schongauer Spanienreise», en Zeitschrift für Kunstgeschichte, 58:1 (1995), pp. 1-2.

${ }^{17}$ Véanse en esta línea los distintos trabajos de M. ${ }^{\mathrm{a}}$ Carmen Lacarra Ducay, «Huella de Martín Schongauer en los primitivos aragoneses», en Archivo Español de Arte, 52:207 (1979), pp. 347-350; «Influencia de Martín Schongauer en los primitivos aragoneses», en Boletín del Museo e Instituto «Camón Aznar», 17 (1984), pp. 15-39 e «Influencia de Martín Schongauer en la pintura gótica aragonesa: nuevas reflexiones», en Artigrama, 32 (2017), pp. 41-70. R. Steven Janke, «Algunos documentos sobre Pablo Hurus y el comercio de libros en Zaragoza a fines del siglo Xv», en Príncipe de Viana: XLVII. Anejo 2. Homenaje a Don José María Lacarra: I Pamplona, IPV, 1986, pp. 335-349. 


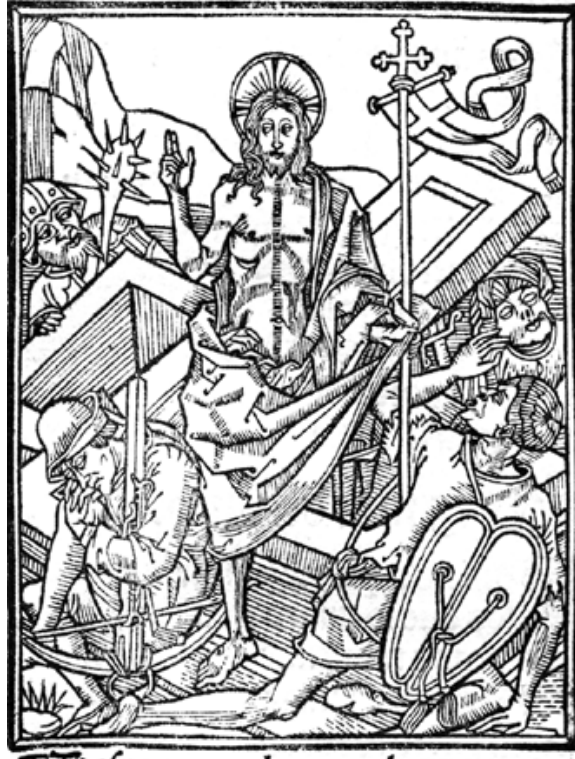

Fig. 1. Resurrección, 92VC y 95VC, n. 33 (f.63r). Imagen propiedad de la BNE.

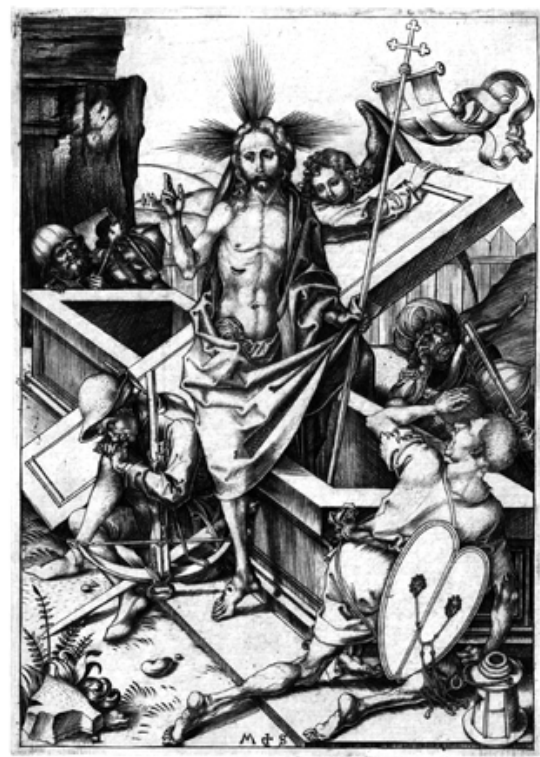

Fig. 2. Martín Schongauer, Resurrección. Courtesy National Gallery of Art, Washington.

(1494) y, sobre todo, en el Viaje de la Tierra Santa de Breidenbach (1498), pero su presencia es aún más amplia y más temprana de lo que se había supuesto, y se remonta, por lo menos, a $1490^{18}$.

Se trata en todos los casos de imágenes que siguen la composición, el movimiento y la situación de las figuras de las calcografías alemanas, pero no exentas de cambios. Sin olvidar que estamos ante un procedimiento distinto, calcografía/xilografía, y ante un menor tamaño, lo que hace que se pierdan detalles, como el fondo paisajístico en el Entierro (n. ${ }^{\circ} 27 \mathrm{~b}$ ), el marco arquitectónico (n. ${ }^{\circ} 20 \mathrm{a}$ ) o se reduzcan figuras; por ejemplo, si comparamos el grabado n. ${ }^{\circ} 33$ (figura 1) con la Resurrección de Martin Schongauer (figura 2) vemos cómo falta la imagen del ángel mancebo que sostiene todavía la pesada piedra de cierre del sarcófago. La disminución del formato, que pasa de los 167x117 mm de la calcografía a los 89x68 mm de la xilografía, junto a las diferencias debidas a la distinta técnica, implican en este caso también la supresión de algunos objetos, como la linterna de los soldados encargados

${ }^{18}$ Véase principalmente Hugh W.M. Davies, Bernhard von Breydenbach and his journey to the Holy Land 1483-4: a bibliography, London, J. \& J. Leighton, 1911; Pedro Tena Tena, «Martin Schongauer y el Viaje de la Tierra Santa de Bernardo de Breidenbach (Zaragoza, 1498)», en Archivo Español de Arte, 272 (1995), pp. 400-404; Carolina Alarcón, Fashioning Schongauer: The Appropriation of Martin Schongauer's Engravings in Aragón, Tesis Master of Arts, Florida State University, 2011. 


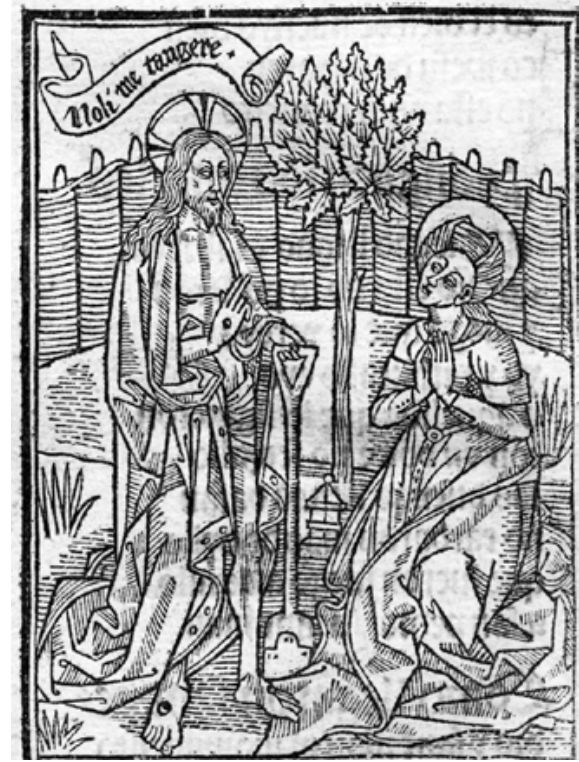

Fig. 3. Jesús bendice a María Magdalena, $92 \mathrm{VC}$ y $95 \mathrm{VC}$, n. 35 (f. $65 \mathrm{v}$ ). Imagen propiedad de la BNE.

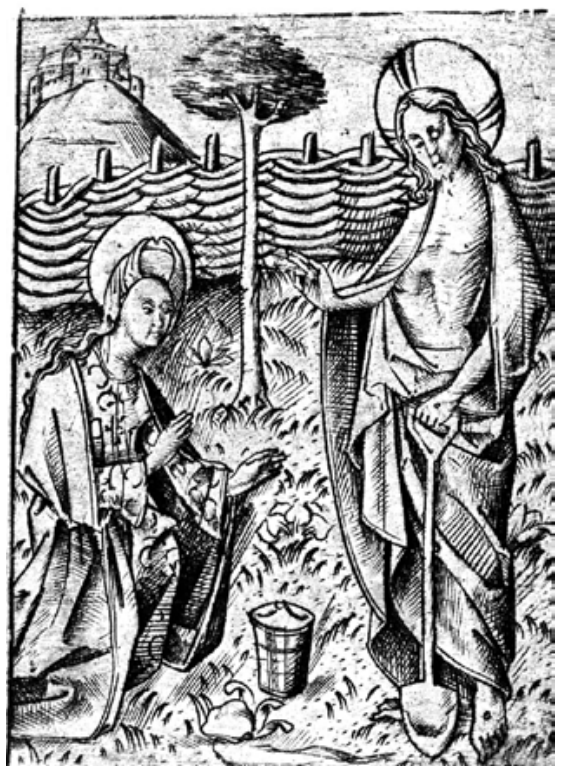

Fig. 4. Israhel van Meckenem, Noli me tangere. British Museum.

de su custodia o la eliminación de ciertos rasgos ${ }^{19}$. El proceso de simplificación es similar en las restantes estampas y afecta al número de figuras -que se reduce-, a los paisajes rocosos y con vegetación árida -que desaparecen o se aminoran (n. ${ }^{\circ} 10$, n. $\left.^{\circ} 11 \mathrm{y} \mathrm{n} .^{\circ} 27 \mathrm{~b}\right)$-, se suprimen las bóvedas o pierden profundidad (n. ${ }^{\circ} 12$, n. $^{\circ} 18$, n. $\left.^{\circ} 20 \mathrm{a}\right)$, faltan detalles, como los perros (n. ${ }^{\circ} 12 \mathrm{y}$ n. $\left.{ }^{\circ} 21\right)$, pero también se añaden, como la filacteria sobre el centurión romano (n. $\left.{ }^{\circ} 24\right)$, y se sustituyen las botas de punta estrecha hasta media pierna por abarcas. Con frecuencia los grabados reflejan la imagen invertida como copias al espejo, lo que sucede en los números 12, 18, 20a, 21y 27b.

Otras imágenes del Cancionero coinciden también parcialmente con modelos germánicos, como la n. ${ }^{\circ}$ 28, la Verónica, que recuerda a una estampa en cobre de Israhel van Meckenem (1440/1445-1503), o la n. ${ }^{\circ} 35$, con la aparición de Cristo resucitado como un hortelano, con la azada en su mano izquierda, bendiciendo a María Magdalena con la derecha, muy similar, pero

\footnotetext{
${ }^{19}$ Para los grabados de Schongauer, véase Max Lehrs, Geschichte und kritischer Katalog des deutschen, niederländischen und französischen Kupferstichs im XV. Jahrhundert. Band 6: Martin Schongauer und seine Schule, Wien, Ges. für Vervielfältigende Kunst, 1927, y las imágenes junto a los comentarios de Sophie Renouard de Busierre, «Catalogue», en Martin Schongauer. Maitre de la gravure rhenane vers 1450-1491, París, Paris-Musées, 1991, pp. 97-264. Reproducciones accesibles en distintas páginas, como German Prints. Albrecht Dürer and his teachers, en línea. Enlace: <http://germanprints.ru/about/index. php?lang=en $>$ [Consulta: 13/01/2020].
} 
invertida, al grabado Noli me tangere del mismo artista. La santa, arrodillada frente a él, tiene a sus pies el pomo del perfume que había llevado al sepulcro y viste de acuerdo con la moda de la segunda mitad del siglo xv (Figuras 3 y 4). La obra de este pintor, grabador y orfebre alemán es difícil de reconocer, ya que en sus grabados reprodujo piezas de muchos artistas, incluso del joven Durero y de Hans Holbein el Viejo -con el que llegaría a colaborar-. Probablemente se formó junto a su padre, artista del mismo nombre, lo que ha complicado la identificación de los trabajos de ambos.

Frente a estos grabados basados directamente en los modelos de Schongauer o van Meckenem, que destacan por su finura, hay otros más realistas, con personajes rígidos, de rostros deformados, que subrayan su maldad, predominio de interiores y marcos arquitectónicos, suelos ajedrezados, escasas perspectivas paisajísticas y pocos espacios en blanco. Responden a este diseño los números 3, 5, 15, 19, 20b y 41. Algunas de estas estampas, más cercanas al estilo de los artistas de los Países Bajos, recuerdan a la Pasión de Delbecq-Schreiber, denominada así por sus primeros poseedores, JeanBaptiste Delbecq y Ludwig von Schreiber, quien se la vendió a aquel, aunque en 1914 fue incorporada a la Real Biblioteca de Bruselas ${ }^{20}$. La historia de este ciclo iconográfico es muy compleja y su estudio no ha estado exento de polémica, tanto por lo referido a su cronología, que se ha supuesto desde 1470-1475 hasta avanzado el siglo XVI, como a su naturaleza, estampas exentas o ilustración de libros, sin olvidar las rivalidades nacionalistas, entre los partidarios de adscribirlo a la historia del grabado germánico y quienes reivindican su origen neerlandés. Las primeras estampas fueron descubiertas a principios del siglo XIX, adheridas a un devocionario manuscrito, y fueron inicialmente datadas entre 1475 (Jan Descamps) y 1490 (Paul Heiz), pero, tras los últimos hallazgos, la serie está constituida por 48 estampas, que abarcan toda la vida de Cristo. En la actualidad la crítica sostiene que se trata de un grupo de grabados neerlandeses, que se integraba en una serie más amplia

\footnotetext{
${ }^{20}$ La Pasión de Delbecq-Schreiber puede verse parcialmente en línea. Enlace: $<\mathrm{http}$ ://www.oldmasterprint.com/delbeq\%20schreiber.htm> [Consulta: 13/1/2020]. Una síntesis de la investigación sobre estos grabados en Wilhelm Molsdorf, Die niederländische Holzschnitt-Passion Delbecq-Schreiber, Strassburg, 1908. Enlace: <https://digi.ub.uni-heidelberg.de/diglit/ebdbd12/0005/image> [Consulta: 13/1/2020]; Louise Hissette, «Notes sur les premiers imprimeurs anversoirs et les gravures de la Passion Delbecq-Schreiber", en Mélanges d'Histoire offerts à Charles Moeller, Louvaine-Paris, Bureaux du Recueil-A. Picard et fils, 1914, vol. II, pp. 13-20; A. J. J. Denle, «Reseña de Vervollständigte Holzschnittfolge der Passion Delbecq-Schreibern, en De Gulden Passer. Jaargang 10 (1932), pp.131-136; Elly CockxIndestege, «De Passie Delbecq-Schreiber houtsneden in drukken 1500-1550», en Ons geestelijk erf, 63: 2-4 (1989), pp 245-278 y Kathryn Margaret Rudy, «Reconstructing the Delbecq-Schreiber Passion (as part of the St Godeleva manuscript)», en Mitteleuropäische Buchmalerei im 15. Jahrhundert. ed. de Jeffrey F. Hamburger y Maria Theisen, Petersberg, Michael Imhof Verlag, 2018, pp. 156-167.
} 
destinada a la ilustración de libros; incluso es posible que previamente formaran parte de incunables y postincunables impresos en Amberes, como la Vita Christi de Ludolfo de Sajonia, de donde habrían sido arrancados para su venta. La disposición de las escenas recuerda también a los grabados de Schongauer, ya que estamos ante modelos iconográficos codificados que los artistas repiten con escasas variaciones, pero su ejecución es muy diferente como se observa comparando la estampa número 15 (figura 5) con una similar, pero también invertida, de la Pasión Delbecq (figura 6).

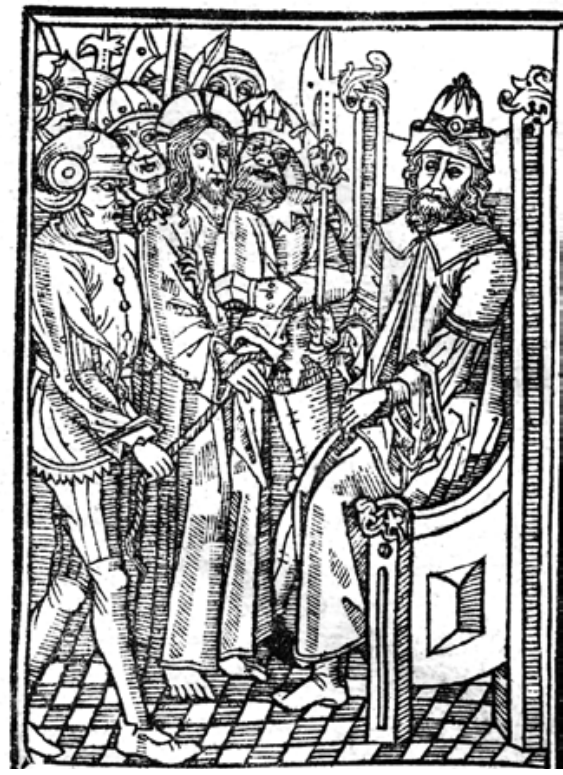

Fig. 5. Jesús ante Poncio Pilatos 92VC y 95VC, n. ${ }^{\circ} 15$ (f. $42 v$ ). Imagen propiedad de l'École Nationale Supérieure des Beaux-Arts de París.

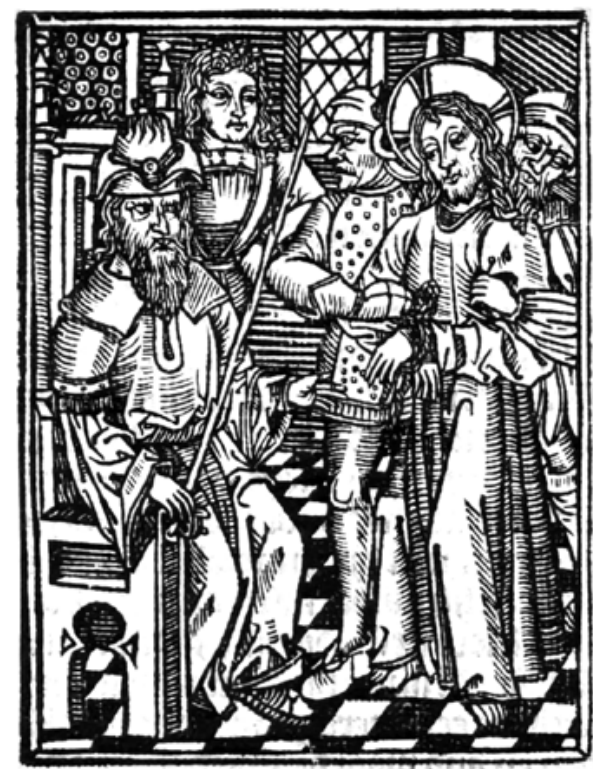

Fig. 6. Jesús ante Poncio, Passion DelbecqSchreiber. Old Master Prints. <http://www. oldmasterprint.com/delbeq\%20schreiber.htm>

Junto a estas imágenes, en las que prima la influencia de modelos alemanes y neerlandeses, otros grabados coinciden con obras religiosas procedentes de talleres lioneses, aunque sus impresores eran también de origen germánico. Muy interesantes son las correspondencias con un libro de Horas en latín, sine notis, casualmente conservado en la citada Biblioteca de Bellas Artes de París, procedente también del fondo Masson. El catálogo de la Biblioteca lo considera impreso antes de finales de 1488 en el taller lionés de Nicolás Philippi, impresor natural de Bensheim (cerca de Darmstadt), pero las bases de datos incunables lo asignan a Juan Trechsel, natural de Maguncia, y lo datan hacia 1489. Este último, al casarse en 1489 con la viuda de 


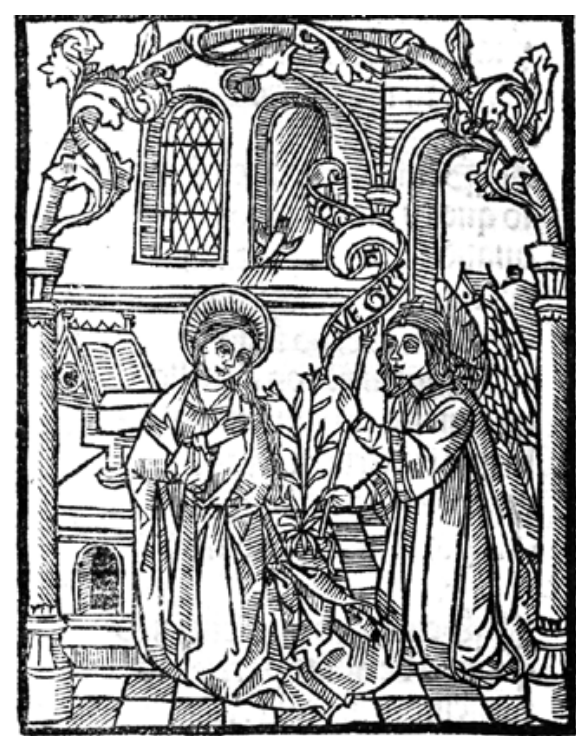

Fig. 7. Anunciación, $92 \mathrm{VC}$ y $95 \mathrm{VC}$, n. $^{\circ} 1$ (f. 3r) y n. $^{\circ} 47$ (f. 74v). Imagen propiedad de la BNE.

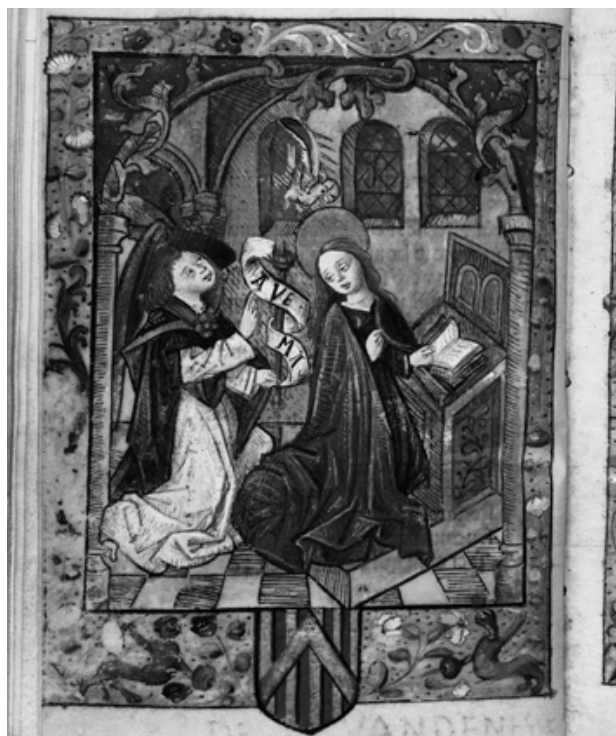

Fig. 8. Anunciación, Horae [Lyon: Nicolás Philippi, c.1488], BENESBA, Masson 0951, f. 26 Foto $($ B Beaux-Arts de Paris, Dist. RMNGrand Palais / image Beaux-Arts de Paris.

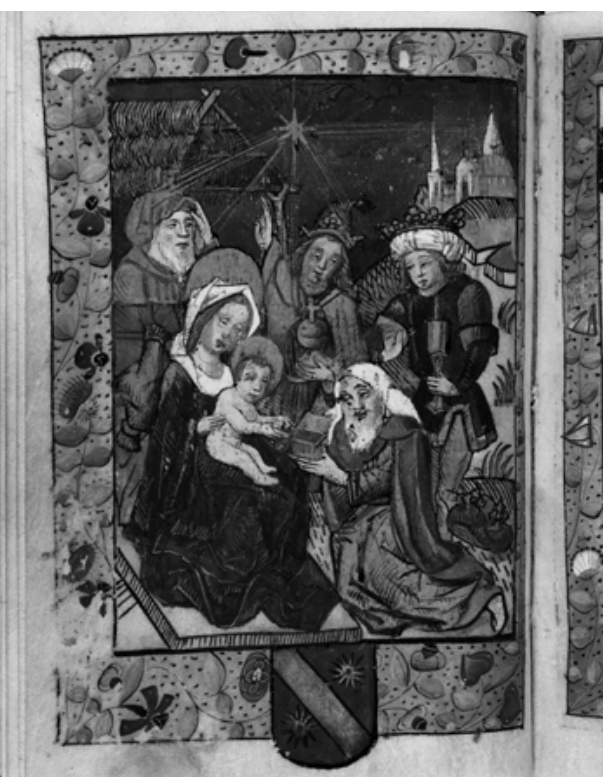

Fig. 10. Epifanía, Horae, [Lyon: Nicolás Philippi, 0c.1488], BENESBA, Masson 0951, f. 44, Foto (C) Beaux-Arts de Paris, Dist. RMNGrand Palais / image Beaux-Arts de Paris.

RPM, 34 (2020), pp. 107-130, ISSN: 1137-8905 
Nicolás Philippi, asumió la dirección de su negocio y sus materiales ${ }^{21}$. De las 12 grandes estampas con las que se ilustran esas Horas, seis de ellas aparecen copiadas en el Cancionero: la Anunciación (n. ${ }^{\circ} 1$; Horae, f. 26v), la Natividad (n. ${ }^{\circ}$ 2, 92VC; Horae, f. 46v), la Epifanía (n. ${ }^{\circ} 4$ y n. ${ }^{\circ} 49$; Horae, f. 44v), la Venida del Espíritu Santo (n. ${ }^{\circ} 51 \mathrm{a} ;$ Horae, f. $74 \mathrm{v}$ ), la Asunción de María (n. ${ }^{\circ}$ 51b; Horae, f. 52r) y la Coronación de la Virgen (n. ${ }^{\circ} 52$; Horae, f. 21v). Al estar coloreadas las estampas del modelo no siempre se perciben con claridad las diferencias, mínimas en algún caso, como la paloma en el n. ${ }^{\circ} 51$, o más evidentes en otros, como en el grabado que representa la Anunciación ( $\left.\mathrm{n}^{\circ}{ }^{\mathrm{o}} 1\right)$, invertido, en el que falta una ventana de la estancia, el atril tiene un formato diferente, y en el que, frente a la tradición, el ángel Gabriel lleva el cetro en su mano derecha y no en la izquierda ${ }^{22}$. Figuras 7 y 8 ; Figuras 9 y 10.

Por último, el origen de otras cuatro imágenes se encuentra en una edición de la Legenda aurea latina de Jacobo de Vorágine impresa en Lyon por Mathias Huss, en 1486: la Matanza de los inocentes (n. ${ }^{\circ}$ 7), el Lavatorio (n. ${ }^{\circ}$ 8), la Natividad (n. ${ }^{\circ} 48,92 \mathrm{VC}$ ) y la Ascensión de Jesús a los cielos (n. ${ }^{\circ}$ 50b, $92 \mathrm{VC})^{23}$. Es muy probable que en este caso no estemos ante copias sino ante el uso de los mismos tacos xilográficos, cuya presencia en el taller de Pablo Hurus por esos años se justificaría por la impresión de dos ediciones de la Leyenda de los santos, sin testimonios conservados, y de las que me ocuparé más adelante.

La única estampa que tuvo que ser entallada ex profeso en el propio taller corresponde a una Virgen del Pilar, sobre la columna, coronada y llena de resplandores, con el niño Jesús en sus brazos, que parece recoger el manto, y unos ángeles alados a cada lado; a su izquierda, el apóstol Santiago el Mayor, vestido de peregrino jacobeo, acompañado de los «siete convertidos», entre los que destaca un bufón o juglar, que podría representar al poeta Gonzalo Martínez de

${ }^{21}$ Signatura Masson 0951. GW 13034 ISTC ih00362700. Horae. Officium BMV secundum usum Romanum. [Lyon: Jean Trechsel, um 1489]; en ambas bases se asigna la impresión a Juan Trechsel. Claude Dalbanne, «Deux Livres d'Heures imprimés à Lyon au Xve siécle», en Gutenberg Jahrbuch (1938), pp. 115-119, atribuye el trabajo a Nicolás Philippe y destaca la similitud con el estilo de los grabados de los talleres alsacianos. Sobre estos impresores, véase Anatole Claudin, Histoire de l'imprimerie en France au $X V^{e}$ et au XVI $I^{e}$ siècle: III, Paris, Imprimerie Nationale, 1904.

${ }^{22}$ En el Breuiarium Immaculate Conceptionis [Colofón: In imperiali ciuitate Toletana. Sin indicación del impresor, pero: Heres Petri Hagenbach. 1508, 14 sept.] hay un grabado similar; información que agradezco a Inmaculada García-Cervigón del Rey.

${ }^{23}$ Las imágenes pueden verse en la Biblioteca Nacional de Francia [Illustrations de Legenda Sanctorum] / Jacques de Voragine, (Lyon) 1486. En línea. Enlace: <https://gallica.bnf.fr/ark:/12148/ btv1b2200010q/f2.item> [Consulta: 18/01/2020]; véase Anatole Claudin, ob. cit., y Fernando Baños Va1lejo, «La transformación del Flos Sanctorum castellano en la imprenta», en Vides medievals de sants: difusió, tradició i llegenda, edició a cura de Marinela Garcia Sempere i M. Àngels Llorca Tonda, Alacant, Institut Interuniversitari de Filologia Valenciana, 2012, pp. $65-97$ (Symposia Philologica; 22). 
Medina, autor de las Coplas de la historia de la sacratíssima Virgen María del Pilar (figura 11). Este grabado tuvo que ser entallado por los mismos artesanos locales que realizaron las otras copias, ya que existen coincidencias en algunos rostros de los convertidos (n. $\left.{ }^{\circ} 22\right)$. Manuel Pedraza especuló con su uso como estampa independiente, pero, sin desechar esta posibilidad, también cabe recordar que las sucesivas ediciones de la Leyenda de los santos iban incorporando en apéndice santos ajenos al calendario litúrgico oficial, los llamados Santos extravagantes, como sucede con santa Engracia, san Valero

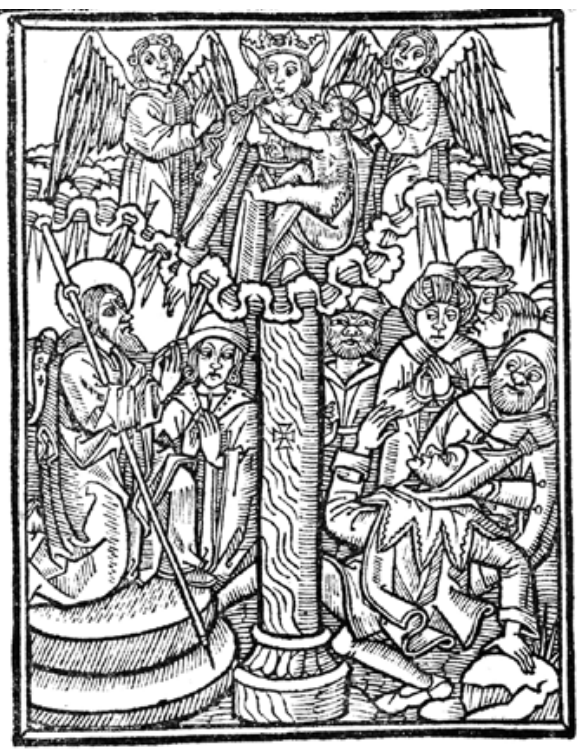

Fig. 11. Virgen del Pilar, 92VC y 95VC, n. 53 (f. 78v). Imagen propiedad de la BNE. o, incluso, el relato de la Edificación de la capilla de Nuestra Señora del Pilar, por lo que pudo prepararse inicialmente con este fin ${ }^{24}$.

Del análisis anterior se desprende que las estampas que adornan el Cancionero en sus dos impresiones, $92 \mathrm{VC}$ y $95 \mathrm{VC}$, no responden a un programa iconográfico único sino que son en su gran mayoría copias de modelos germánicos y franceses, entre otros, ampliamente difundidos en la iconografía cristiana de la época, no solo a través de la imprenta, sino también en otras manifestaciones artísticas, como la pintura sobre tabla ${ }^{25}$.

\footnotetext{
${ }^{24}$ Manuel José Pedraza Gracia, «El grabado en Aragón en la Baja Edad Media», en La miniatura y el grabado de la Baja Edad Media en los archivos españoles, coord. de M. ${ }^{a}$ del Carmen Lacarra Ducay, Zaragoza, Institución Fernando el Católico, 2012, pp. 75-101; Emilio Alfaro, Estampas de Nuestra Señora del Pilar de Zaragoza, Zaragoza, La Cadiera, 1950; el mismo grabado sigue usándose en el taller en el siglo XvI, como se ve en Cato et contemptus. Impressum Cesarauguste: [Jorge Coci], 1508, 30 Madii (Norton, n. ${ }^{\circ}$ 623). En la Sacristía Mayor de la Basílica de Nuestra Señora del Pilar se conservan tres grandes sargas, pintadas al temple, la primera de las cuales sigue una iconografía similar a la estampa de Hurus; véase M. ${ }^{a}$ Carmen Lacarra Ducay, «Venida de la Virgen del Pilar a Zaragoza», en D. Buesa Conde y P. J. Rico Lacasa, El espejo de nuestra historia. La Diócesis de Zaragoza a través de los siglos, Zaragoza, Ayuntamiento de Zaragoza-Arzobispado de Zaragoza, 1991, pp. 80-83.

${ }^{25}$ Algunos modelos llevaban tiempo recreándose en la imprenta incunable alemana. Por ejemplo, en el Speculum humanae salvationis [Speyer]: [Peter Drach der Ältere], [c. 1480]. - ISTC is00665000 GW43020, hay xilografías similares a los números 2, 6 y 9; también existen claras correspondencias entre los grabados n.$^{\circ} 1$ y n. ${ }^{\circ} 4$, la Anunciación y la Epifanía, y las pinturas góticas del retablo mayor de Anento, n. ${ }^{\circ} 39$, la Ascensión de Jesús a los cielos, y el Retablo de San Salvador (Ejea de los Caballeros), o n. ${ }^{\circ}$ 19, los Improperios, y las pinturas góticas del retablo mayor de Villaroya del Campo, todos en la provincia
} 


\section{Conclusión: el almacén de estampas devocionales del taller de Pablo Hurus}

Las 60 estampas que adornan el Cancionero permiten, recurriendo a la feliz expresión de Antonio Rodríguez Moñino, considerarlo un Libro de Horas impreso. En una medida de ahorro, habitual en los talleres, Hurus se sirvió para ilustrarlo del amplio número de estampas devocionales que almacenaba, y que podemos considerar de su propiedad, puesto que hará uso de ellas en el futuro, y seguirán usándose por los herederos de su oficina hasta mediados del siglo siguiente ${ }^{26}$. Buena parte, si no todas, habían decorado entre $1490 \mathrm{y}$ 1492 diversas obras, aunque a veces la ausencia de ejemplares o la existencia de testimonios incompletos nos impida documentarlas con certeza. Con seguridad, se habían utilizado en dos obras: Horae ad usum Romanum y Aurea expositio hymnorum. Conviene recordar que en Zaragoza se imprimieron tres libros de horas en el periodo incunable, con ilustraciones. Del primero, posiblemente publicado hacia 1490, solo se conserva un testimonio incompleto en la Hispanic Society of America, que conserva ocho estampas; solo una de ellas, la Natividad (n. ${ }^{\circ}$ ), coincide con el Cancionero, aunque es muy probable, que compartiera diez, como sucede con la edición del mismo taller de 1499 (n. ${ }^{\circ} 1$, n. ${ }^{\circ} 5$, n. $^{\circ} 9$, n. $^{\circ} 11$, n. $^{\circ} 20 \mathrm{a}, \mathrm{n} .{ }^{\circ} 22$, n. $^{\circ} 24$, n. $\left.^{\circ} 27 \mathrm{a}, \mathrm{n} .{ }^{\circ} 32 \mathrm{y} \mathrm{n.}{ }^{\circ} 33\right)$. La segunda obra que incorporó algunos de estos tacos meses antes fue una Aurea expositio hymnorum una cum textu, edición y anotación de Antonio de Nebrija, impresa a comienzos de 1492 (26 de enero), con 27 estampas, en su ejemplar completo, algunas de ellas utilizadas también meses más tarde en el

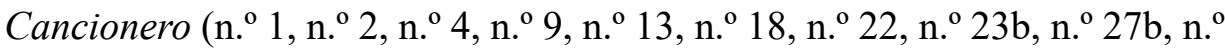
29, n. ${ }^{\circ} 39$, n. ${ }^{\circ}$ 51a, n. $\left.{ }^{\circ} 52\right)^{27}$. A estas se suma la estampa de La Muerte (n. $\left.{ }^{\circ} 54\right)$, empleada en el Cordial de las cuatro cosas postrimeras, 1491 (21 de julio), que solo aparece en $92 \mathrm{VC}$.

De mayor interés, sin embargo, puede ser la ayuda que un estudio de esta índole puede brindar como apoyo para corroborar la posible existencia de obras perdidas así como para reafirmar las redes de conexión entre talleres. Tenemos la seguridad de que Hurus elaboró dos Leyendas de los santos, sin ejemplares conservados, pero atestiguadas por documentación: una en 1490

de Zaragoza; véanse las reproducciones en María del Carmen Lacarra Ducay, Blasco de Grañén, pintor de retablos (1422-1459), Zaragoza, Institución Fernando el Católico, 2004, pp. 34, 84, 118, 127 y 132.

${ }^{26}$ No solo se sirve de ellas Coci sino que todavía las usan sus sucesores avanzando el siglo XvI, como en las Epistolas y evangelios en romance [Zaragoza: ¿Nájera-Bernuz?, 1537-1550?].

${ }^{27}$ El ejemplar de la Biblioteca de Palacio Real, DIG/I/142_B, está mútilo de las hojas d4 y d5, lo que implica la ausencia de tres estampas, no repertoriadas por Martín Abad, n. ${ }^{\circ} 188$, que, sin embargo, sí se localizan en el ejemplar de la Universidad de Valladolid, signatura U/Bc IyR 108 (3), completo, accesible en: $<$ http://almena.uva.es/record=b1475317 S1* spi $>$ [Consulta: 24/01/2020]. 
(Zar1490*) y otra $1492(\text { Zar1492* })^{28}$. Es probable que a la sección principal se antepusieran unos preliminares, con la Pasión debida a Gauberto Fabricio Vagad (cronista del Reino de Aragón desde 1495), una traducción parcial de los materiales sobre la Pasión presentes en el Monotheseron de Jean Gerson y otras piezas religiosas ${ }^{29}$. Como señala Fernando Baños, alguna de estas ediciones, o las dos, pudieron estar ilustradas con el mismo juego de tacos utilizados en Lyon: M. Huss, 1486, lo que le lleva a concluir que «las xilografías lyonesas estuvieron en Zaragoza en el taller de Hurus en la época en la que editó el flos sanctorum castellano» ${ }^{30}$.

Podemos también especular con que alguna de las estampas se incorporara a esa Biblia istoriada que, según el documento de 4 de abril de 1478, dado a conocer por Encarnación Marín, se comprometía Hurus a imprimir y del que tampoco quedan lamentablemente testimonios. El encargo fue hecho por varios conversos de Calatayud, porque el original en el que debía basarse estaba traducido del hebreo, y en las pormenorizadas capitulaciones se detalla la materia escriptoria (papel, excepto cuatro en pergamino), el formato (mayor), el tipo de letra, el número de ejemplares (79) y se especifica que «las quales dichas setanta et nueve biblias han de seyer istoriadas de tinta negra de emprenta las quatro istorias sian a vista del dito Paulo encargandole su consciencia» ${ }^{31}$. ¿Cómo serían estas cuatro imágenes que se dejaban a gusto de Hurus? Dada la fecha del documento, el resultado implicaría una tempranísima impresión ilustrada.

Tanto la procedencia de algunas imágenes como su copia posterior nos reflejan las relaciones comerciales que mantenía Pablo Hurus con otros talleres, dentro y fuera de España. Los compromisos que seguía manteniendo con la compañía de Ravensburg le obligaban a viajar periódicamente a Alemania, recorriendo la ruta que conectaba con el sur a través de Basilea y Lyon. No es

\footnotetext{
${ }^{28}$ La impresión de 1490 está testimoniada por un documento de 8 de enero de 1490, en el que el maestro Juan Hurus vende setecientos ejemplares de la obra a Luis Malférit, encargándose de su transporte a Medina del Campo o Valladolid. El trabajo habría sido iniciado por Juan Hurus y culminado por Pablo Hurus. La edición de 1492 está atestiguada por un documento de 7 de marzo de 1492, en el cual, el mercader Pedro Porras, vecino de Burgos, solicita ochocientos ejemplares «nuebament emprentados [...] en la present ciudad de Caragoca». De acuerdo con este texto, Pablo Hurus se encargaría del transporte de los ejemplares hasta Medina del Campo, renunciando no solo a vender en Castilla los volúmenes que quedaban en su imprenta, sino incluso a publicar más ejemplares de ese título en un plazo de dos años; véase Pallarés Jiménez, ob. cit, pp. 114-117.

${ }^{29}$ José Aragüés, «La Leyenda de los santos: orígenes medievales e itinerario renacentista», en Memorabilia, 18 (2016), pp. 133-187.

${ }^{30}$ Baños Vallejo, art. cit., p. 81.

${ }^{31}$ Encarnación Marín Padilla, «Pablo Hurus, impresor de Biblias en lengua castellana en el año 1478», en Anuario de Estudios Medievales, 18 (1988), pp. 591-603; Pallarés Jiménez, ob. cit., p. 72 y pp. 588-598.
} 
extraña, pues, la coincidencia de tacos con la Legenda aurea latina de Jacobo de Vorágine llevada a cabo en esa ciudad francesa por Mathias Huss en 1486, o la similitud de modelos con las Horas impresas quizá entre 1488-1489. Es bien conocida la dependencia que la imprenta burgalesa de Fadrique de Basilea mantenía con la zaragozana hasta el punto de ser calificada «casi como de una sucursal en Castilla del taller aragonés $\rangle^{32}$. En algunos casos cabe sospechar que los tacos viajaron a Burgos, donde encontramos diez estampas en la obra de Johannes Gerson, Passion del eterno príncipe Jesuchristo en romance [Burgos: Fadrique de Basilea, c. 1493], y continúan decorando el Fasciculus mirrhe [Burgos: Juan de Junta, 1531] o La pasión trobada de Diego de San Pedro [Burgos: Juan de Junta, c. 1530-1540].

El análisis abordado nos permite concluir que, con la excepción de la estampa dedicada a la Virgen del Pilar, la mayoría habrían sido copiadas o retocadas a partir de modelos europeos en distintos momentos para después pasar a formar parte del acervo del impresor, como lo atestigua su continuada reutilización. Pablo Hurus, caracterizado por su visión comercial, rentabilizó esta inversión, puesto que este material se convertirá en habitual en el taller, y en el de sus sucesores, para ilustrar textos devocionales en latín y romance e incluso sus motivos aún se reconocen en los toscos grabaditos que decoran algunos pliegos poéticos religiosos. El resultado fue bien recibido por los lectores y, pese a tratarse de ejemplares costosos, el éxito forzó a una nueva impresión tres años después. Con el hallazgo ahora de nuevos testimonios es posible reconstruir la filiación de algunas ilustraciones, corroborar la hipótesis de obras perdidas o trazar las rutas por las que han viajado algunos tacos. En resumen, estas dos ediciones, aunque no cuentan con un programa iconográfico uniforme, muestran una inusual decoración. Sus 60 estampas, retomadas de modelos foráneos, nos confirman que en torno a 1490 , si no es antes, en el taller de los hermanos Hurus había artesanos capaces de producir copias de calidad.

Recibido: $7 / 1 / 2020$

Aceptado: 28/04/2020

\footnotetext{
${ }^{32}$ Mercedes Fernández Valladares, La imprenta en Burgos (1501-1560), Madrid, Arco/Libros, 2005, vol. I, p. 130.
} 


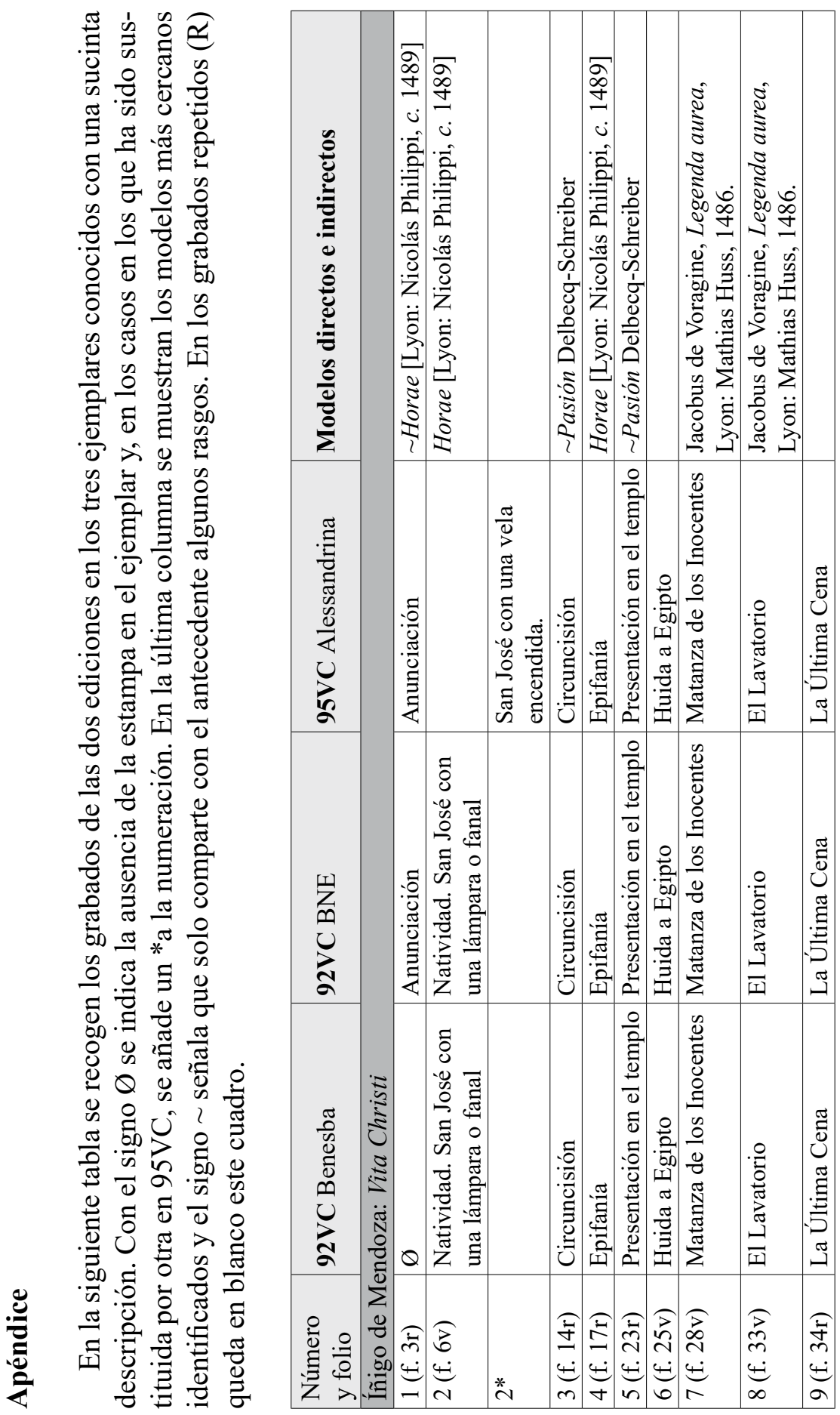




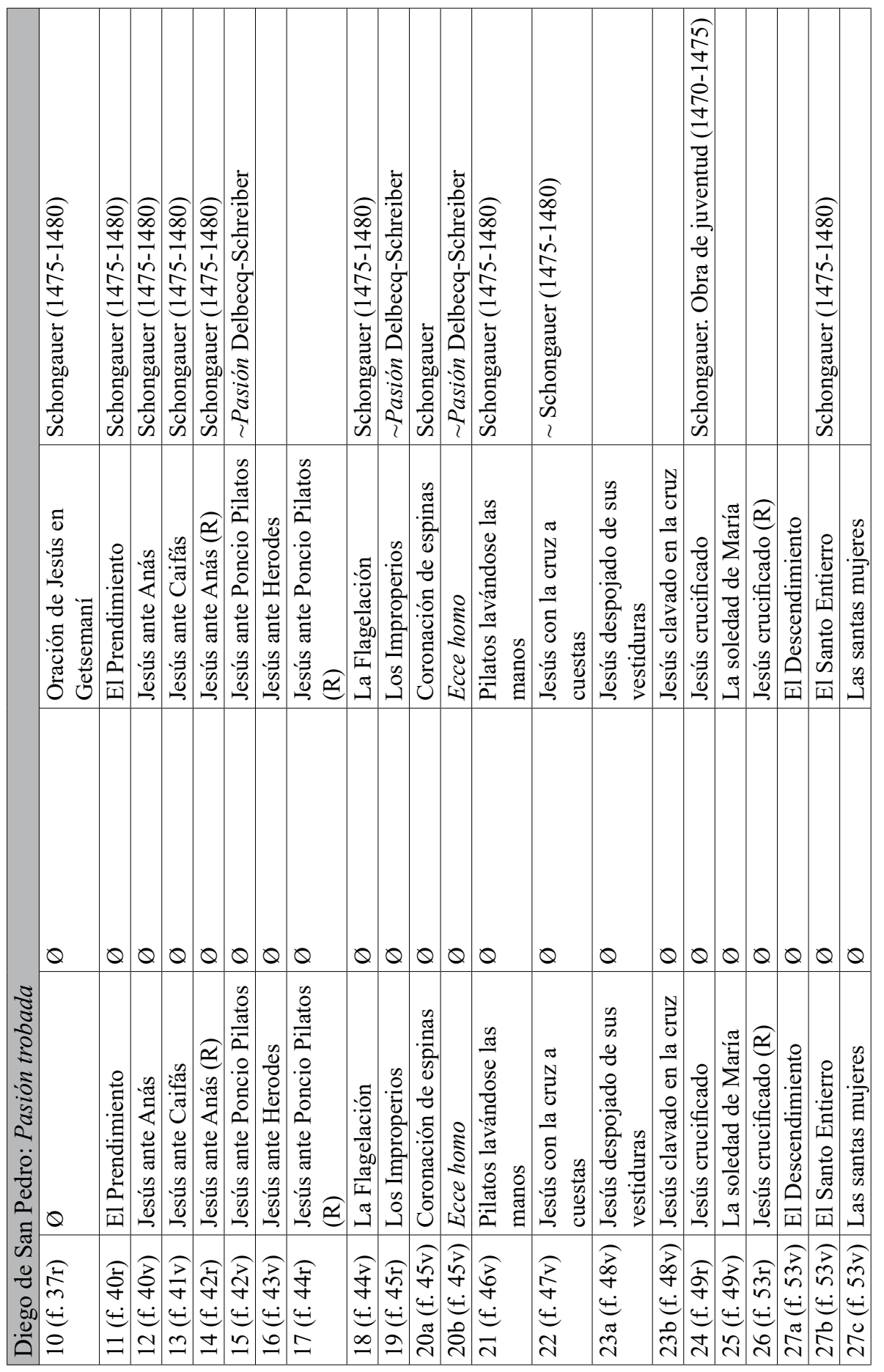









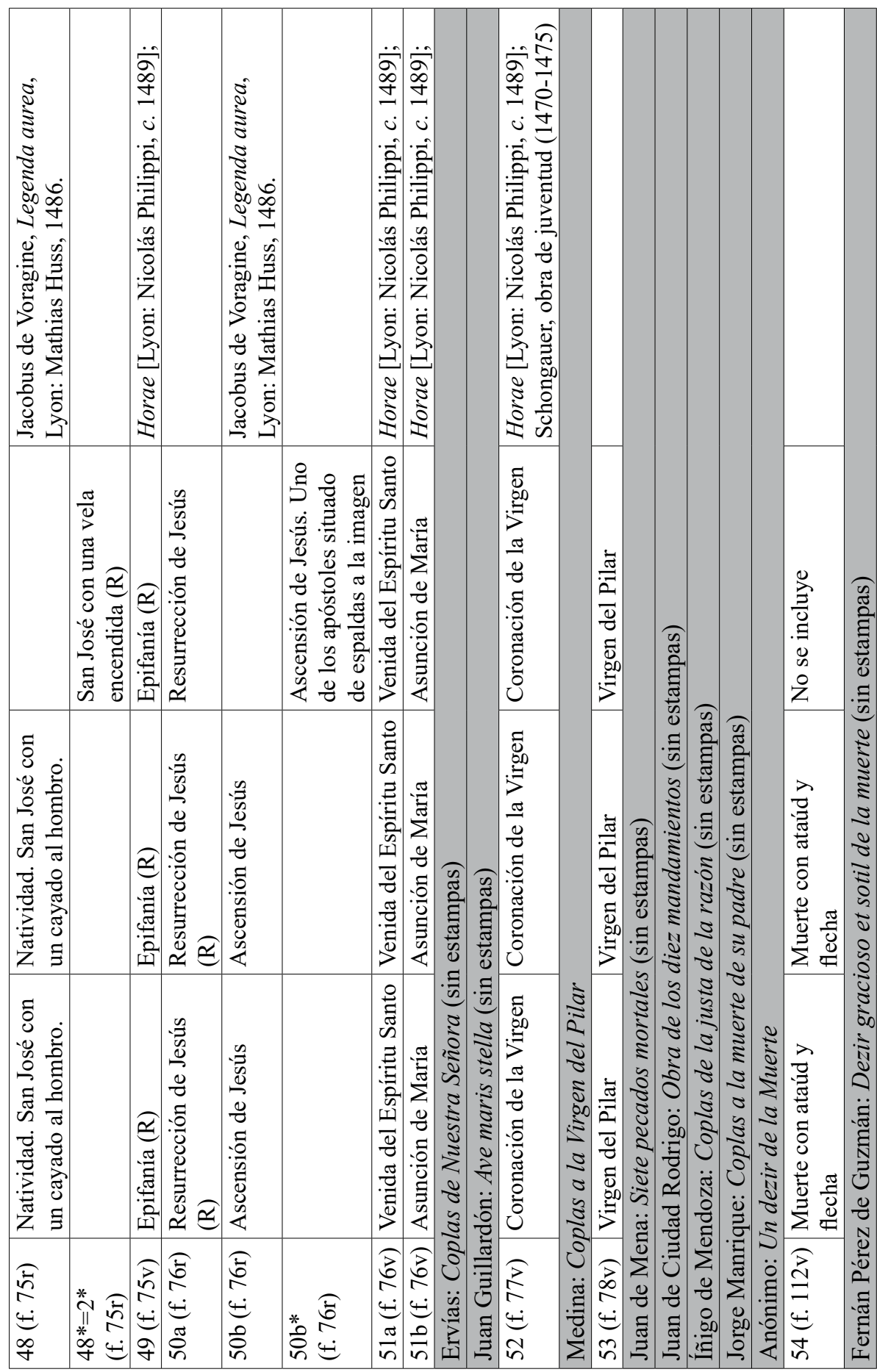


$\cos 8$

\title{
EL CICLO DE IMÁGENES DEL CANCIONERO DE ZARAGOZA \\ EN LOS TESTIMONIOS INCUNABLES (92VC Y 95VC)
}

RESUMEN: En 1492 se imprimió en el taller de Pablo Hurus un conjunto de obras poéticas devocionales, que contaban también, muchas de ellas, con difusión manuscrita e impresa independiente. Tres años después (1495) se preparó en el mismo taller una nueva edición a plana y renglón de la anterior. Al éxito de la obra contribuirían, sin duda, los 60 (59) grabados que no habían sido objeto de estudio detenido debido a los avatares sufridos por los ejemplares. En el artículo se estudian las estampas, se analiza su función, sus posibles modelos y su reutilización.

Palabras Clave: Cancionero. Incunables. Grabados. Schongauer. Pablo Hurus.

\section{THE CYCLE OF IMAGES FROM THE CANCIONERO OF ZARAGOZA IN THE INCUNABULA TESTIMONIES (92VC AND 95VC)}

\begin{abstract}
In 1492 was printed in Pablo Hurus' workshop a collection of devotional poetry, many of which were also distributed by hand and printed independently. Three years later (1495) a new edition was prepared in the same workshop. The 60 (59) engravings that, until now, had not been studied in detail due to the ups and downs suffered by the copies, undoubtedly contributed to the success of the work. The article studies the woodcuts, analyzes their function, their possible models and their reuse.
\end{abstract}

KeYwords: Songbook. Incunabula. Engravings. Schongauer. Pablo Hurus. 